Piotr Gawliczek (2019) Innovative ICT solutions and/within/for changing security environment. Case study - NATO DEEP ADL Portal and Social Media. Social development \& Security. 9(4), 111 - 119. DOI: http://doi.org/10.33445/sds.2019.9.4.8

\title{
Innovative ICT solutions and/within/for changing security environment. Case study - NATO DEEP ADL Portal and Social Media
}

\section{Piotr Gawliczek}

University of Warmia and Mazury in Olsztyn, Poland, e-mail: pgawliczek@gmail.com,

Ph.D, Assoc. Prof.,

ADL Coordinator.

\section{OPEN ACcess}

Article history:

Received: June, 2019

1st Revision: July, 2019

Accepted: August, 2019

Abstract: The Defence Education Enhancement Programme (DEEP) is a vehicle for reform, providing tailored practical support to individual countries in developing and reforming their professional military education institutions. Through faculty development, curriculum development and peer-to-peer consultations, the DEEP Programme fosters defence capacity building, cooperative capability development and standardisation and promotes interoperability of processes and methodologies to enhance democratic institutions. With the support of more than 350 experts from approximately 75 defence education institutions in NATO member and partner countries, DEEP provides host countries with the assistance needed to respond to the most pressing requirements for modernisation and reform. In this context and based on requests from the ADL expert community in DEEP Partner countries, IS-PASP has taken the initiative to provide a NATO/DEEP-owned Advanced Distributed Learning (ADL) Portal to the DEEP community. The purpose of the DEEP ADL Portal is two-fold: (1) serve as a repository/ catalogue of online courses used by the professional military education institutions in NATO Allies and DEEP Partner countries; (2) facilitate ADL Designers in NATO Allied and DEEP Partner countries in the design of online courses by enabling them to: (1) exchange their expertise, knowledge and ideas on ADL; and (2) design online courses. The Portal aims at being a comprehensive solution that will not only allow the deepening of cooperation within the DEEP Programme, but also influence the dissemination of ideas in defence education and thus increase the reach of the programme. At the same time, it will create a compendium of expertise in the use and implementation of new technologies in defence education and training. Working together with Partners and sharing resources and courses will empower NATO in its objective of modernising and reforming military education institutions.

Keywords: NATO, DEEP, ADL, LMS ILIAS, Social media.

\section{Introduction}

The purpose of the article is to present the importance of the innovative information and communications technologies (ICT) within security environment. As the case study Defence Education Enhancement Programme (DEEP) is described. The thesis states, that DEEP is the efficient vehicle for reform, providing tailored practical support to individual countries in developing and reforming their professional military education institutions. The significance of the article relates to the questions on the issues of the faculty development, curriculum development and peer-to-peer 
consultations. They relate to the DEEP Programme as the forge to foster defence capacity building, cooperative capability development and standardisation and interoperability of processes and methodologies to enhance democratic institutions. By supporting democratic institutions, it makes an important contribution to NATO's efforts to project stability in the Euro-Atlantic area and beyond, as stated by the official NATO website on the topic of NATO DEEP [1]. On the other hand, the quality of the education really matters. According to metaanalysis data, the most important factor affecting student learning is teacher [2]. Of importance is to stress the importance of the latest development within information technology sector [3]. It influences the social realm, involving educational and training process [4]. Also, the importance of social media should be mentioned [5].

\section{Defence Education Enhancement Programme - from idea into practice}

At the NATO Summit in Istanbul in 2004, Allies launched the Partnership Action Plan on Defence Institution Building (PAP-DIB), which was endorsed by leaders from partner countries in a meeting of the Euro-Atlantic Partnership Council (EAPC). PAPDIB reflects common views on modern and democratically responsible defence institutions. It provides a definition of defence reform and a framework for common reflection and exchange of experience on related problems. It aims to assist interested partners to reform and restructure their defence institutions to meet their needs and international commitments. To support the implementation of the defence education component of PAP-DIB, in February 2006, Allies launched the Education and Training for Defence Reform Initiative. Its aim is to create an EAPC-wide collaborative mechanism and tools to help implement PAP-DIB by supporting education of civilian and military personnel in efficient and effective management of national defence institutions under civil and democratic control. This led to the development of the Defence Education Enhancement Programme by NATO together with the PfP Consortium. Support for defence education, training and capacity-building was reaffirmed in a new Policy for an Active Engagement in Cooperative Security: a More Efficient and Flexible Partnership Policy agreed by NATO Foreign Ministers in April 2011. At successive NATO Summits - most recently, at the Brussels Summit in July 2018 - Allies have declared their commitment to strengthening cooperation with partners, upon request, to build stronger defence institutions, improve good governance, enhance their resilience, provide for their own security, and more effectively contribute to the fight against terrorism. This investment in partners' security contributes to Alliance security. There is a clear role for defence education in developing stable defence and military institutions. The defence and related security sector require an integrated strategic approach. Joint training and joint planning with partners and representatives from international organisations and civil society are especially important. Defence education cultivates an aspiration to excellence and contributes to NATO's efforts to project stability and build defence capacity in the region. Building up a good defence education system takes time. Modernising defence training and education provides an important opportunity to respond to the prevailing deficits in global governance. To get military education right, armed forces must have 
a clear and comprehensive vision of the military education and training system for officers - from the cadet course training lieutenants to the colonels' course to educate strategists. Research and education must be tied together. To maintain a sound education system, curricula ought to be developed by education professionals in dialogue with defence staffs and respective institutions. It should be considered, that spectrum of the current security environment is changing, and the hybrid dimension is of importance [6].

\section{Defence Education Enhancement Programme in action}

DEEP works with partner nations to help identify the needs and gaps of education institutions in the defence and military domain. The two main components curriculum development and faculty development - are bolstered by dialogue between institutions in partner and NATO countries as well as peer-to-peer consultations among subject-matter experts. DEEP helps partners to modernise and professionalise the organisational structure of professional military education institutions and provides solutions to build quality assurance processes within the system. The DEEP Programme works closely with professional military education institutions to assist in the development of specific curricula on virtually any subject requested by the partner nation. Since 2008, the Partnership for Peace Consortium (PfPC) of Defense Academies and Security Studies Institutes, working in coordination with the NATO International Staff, has developed a number of different curricula - designed for employment by defense education institutions. They are designed to provide partner countries with in-depth learning objectives and curriculum support for academic courses in professional military education (PME) schools. NATO has noted that these reference curricula can serve as tools for partner countries in the design and development of courses, modules and programs for professional officer military education and the enhancement of military interoperability between NATO and partners, as mentioned in the Reference curricula Available for DEEP/AMEP Utilization. To support this work, NATO and the PfP Consortium have produced reference curricula. First one is the Partnership Plan for Defence Institution Building (PAP-DIB), which aims to provide in-depth learning objectives and curriculum development support for academic courses focused on defence institution building or reform. The PAP-DIB reference curriculum informs that in part by the typical academic programs and courses found in Western civilian and military academic institutions [7]. Second one is on Professional Military Education for Officers [8], developed by a multinational team of defence educators and practitioners, aims to provide in-depth learning objectives and curriculum support for academic courses related to officer professional military education; an important contribution to defence education and enhancement of military interoperability between NATO and its partners. This curriculum consists of three levels: 1) Pre-Commissioning, 2) Junior Officer and 3) Intermediate Officer; and three themes: 1) Profession of Arms, 2) Command, Leadership and Ethics and 3) Defense and Security Studies. The three phases and themes have been carefully chosen to encompass the broadest spectrum of officers and to provide the most pertinent level of education for a medium size armed 
force. Third one is on Professional Military Education for Non-Commissioned Officers [9]. Is also developed by a multinational team of defence educators and practitioners, is designed to provide in-depth learning objectives and curriculum support for academic courses related to Non-Commissioned Officer (NCO) professional military education; an important contribution to defence education and enhancement of military interoperability between NATO and its partners. This curriculum consists of four levels: 1) Primary, 2) Intermediate, 3) Advanced and 4) Command Senior Enlisted Leader; and three themes: 1) Profession of Arms, 2) Leadership and Ethics and 3) NonCommissioned Officer Core Competencies. The four levels and three themes have been carefully chosen to encompass the broadest spectrum of NCOs and to provide the most pertinent level of education for a medium size Armed Forces. The fourth is on Cyber Security [10] and aims to provide in-depth learning objectives and curriculum support for academic courses broadly related to Cybersecurity. This curriculum consists of four themes: 1) Cyberspace and the Fundamentals of Cybersecurity, 2) Risk Vectors, 3) International Cybersecurity Organizations, Policies and Standards and 4) Cybersecurity Management in the National Context. The four themes and associated blocks have been carefully chosen to encompass the broadest spectrum of Cybersecurity issues and topics, and to provide the most pertinent level of education. Fifth one is on Counterinsurgency [11] and the document aims to serve as a reference, a starting place, for individuals or organizations in NATO member states and partner countries looking to develop and/or supplement their professional military education (PME) in the area of Counterinsurgency (COIN). The sixth one is on Building Integrity (BI) [12], developed by NATO International Staff-led working group of subject matter experts (SMEs) from Allied and partner nations, aims to assist both NATO Allies and partners in enhancing education and training, and the mainstreaming of BI. In addition, this document provides BI specific topics that can be embedded into existing courses on good governance and anti-corruption or tailored to meet specific national requirements and objectives in both of these areas or related subjects DEEP features specialised engagement on pedagogy to provide institutions and instructors with access to the latest teaching methods and to support their efforts to foster critical thinking in the classroom. New curricula is being developed - on Counter-Terrorism. Relying on voluntary contributions, NATO steers policy and the PfP Consortium leads on academic support facilitating the network of institutions and individual academics and practitioners who contribute through the PfP Consortium's Education Development Working Group. NATO draws on an ad-hoc network of contributors who offer their services through an annual Clearing House on Defence Education that serves as a forum for Allies and partners to coordinate efforts and inform institutions and countries about the status of the various DEEP programmes. Led by Bulgaria, Canada, the Czech Republic, France, Italy, Lithuania, Poland, Romania, Slovakia, Spain, Switzerland and the United States, with the support of the PfP Consortium, the annual Clearing House is an effective tool to identify partner requirements and align them with donor expertise [1]. It is connected with the strategic communications specificity - to deliver message [13]. 


\section{Practical dimension and forms of DEEP}

Any NATO partner country that has an individual bilateral cooperation plan with the Alliance can request the development of a DEEP programme. When a country requests a DEEP programme, a multinational DEEP assessment team visits the country to scope out the potential programme with their interlocutors. Based on the assessment visit, the DEEP team creates a proposed action plan, usually with a three-year duration. Once the partner approves the action plan and funding is identified, the DEEP academic lead assembles and allocates the appropriate expertise from a vast transatlantic network of experts that is managed jointly by NATO and the PfP Consortium's Education Development Working Group. The level of progress and transformation depends on how much effort education institutions make to operationalise change derived from the conduct of DEEP activities, particularly in the areas of faculty development and curriculum development. Categories of measure of effectiveness vary from country to country and the following are identified as the most relevant: (1) Adoption of modern professional military education academic structures and degree requirements; (2) Adoption of modern teaching methodologies by professional military education faculty; (3) Inclusion of new subject matter in existing course curricula and development of new courses; (4) Adoption of Non-Commissioned Officers' Education; (5) Support of Senior Partner Nation and Defence Education Institution Leadership for DEEP programmes; (6) Contribution of Partner Nation Educators and NCO Experts (Military and Civilian) in DEEP programmes. DEEP objectives are met when the partner's professional military education institution is self-sufficient and no longer requires external assistance, its curriculum satisfies all course needs, and a process exists to ensure a continuous curriculum review. The professional military education institution faculty should be able to teach all classes using modern teaching techniques and have an internal sustainment capability to train their new faculty in modern teaching methodology. For example, in 2017, Cuiavian University in Wloclawek agreed to support NATO's work with partners on defence education through ADL [14]. The series of events was organised. As the result the National Defence University of Ukraine (NDUU) has developed its own e-learning courses for officers that would complement the current stationary courses and enable focusing on a practical and casescenario based instruction [15]. As another example of the cooperation within the NATO Defence Education Enhancement Programme for Ukraine, experts from allied countries visited the Serhiy Korolylov Zhytomyr Military Institute (ZMI) in September 2018 to assist with the development of a new course on cybersecurity [16]. The Reference Curriculum on Cybersecurity developed by DEEP and the PfP Consortium serves as the academic basis for this course. The "Cybersecurity Awareness Micro Course - 10 Principles of Cybersecurity" is now available in Ukrainian [17]. Securing cyberspace, therefore, entails a number of considerations to mitigate risks and threats while encouraging accessibility and openness across various types of interconnected networks and devices. Establishing the necessary balance between access, usability and security is the core challenge. As part of the DEEP agenda, experts from across NATO continued to support the Military Academy in Skopje with a number of activities throughout 2018 [18]. 


\section{NATO DEEP ADL Portal - case study}

ADL is an education method that is delivered electronically through a computer or other device. It uses online services that enable users to create courses, simulations, or other educational experiences. It is becoming an essential part of professional military education and is also one of the fastest growing areas of NATO's education and training capabilities in the area of technology. DEEP uses this tool to provide education, training and performance support to partner countries. There are many examples, as far as the ADL agenda is concerned. In this context and based on requests from the ADL expert community in DEEP Partner countries, the decision was taken to initiate a NATO/DEEP-owned Advanced Distributed Learning solution to the DEEP community. The purpose of the DEEP ADL solution is two-fold: (1) serve as a repository/catalogue of online courses used by the Professional Military Education institutions in NATO Allies and DEEP Partner countries; (2) facilitate ADL Designers in NATO Allied and DEEP Partner countries in the design of online courses by enabling them to exchange their expertise, knowledge and ideas on ADL, and design online courses. It is a comprehensive solution that not only allows the deepening of cooperation within the DEEP Programme, but also influences the dissemination of ideas in defence education and thus increase the reach of the programme. At the same time, it creates a compendium of expertise in the use and implementation of new technologies in defence education and training. Working together with Partners and sharing resources and courses will empower NATO in its objective of modernising and reforming military education institutions. Due to this, the DEEP ADL solution targets both: (1) the ADL expert community that will benefit from expertise and knowledgesharing on online course design, (2) students from NATO Allies and DEEP Partner countries that will be able to follow courses through the NATO/DEEP-owned Advanced Distributed Learning (ADL) solution [19]. The utilities related to the portal are shown on the figure 1 .

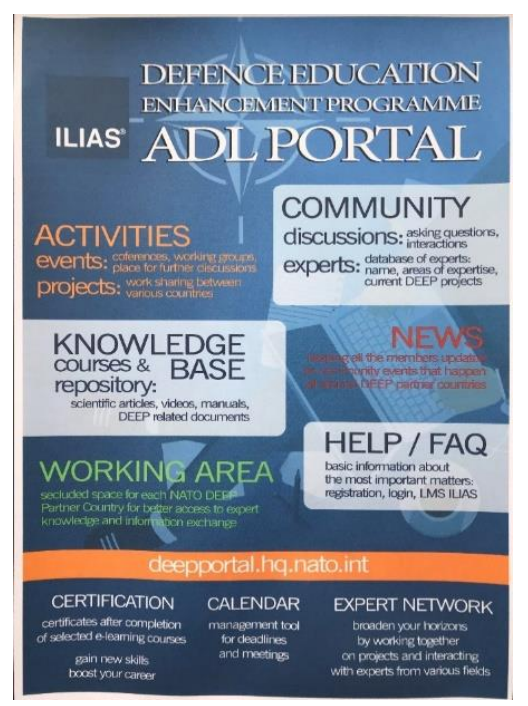

Figure 1 - NATO DEEP ADL Portal (idea) 
To support the involvement of the respective sides and to engage the partners, the role of social media was taken into account. Considering the feasible option, after having coordinated the issue on the NATO HQ level, Twitter account has been officially introduced @DEEP_ADL.

\section{Conclusions}

The purpose of the article was to present the Defence Education Enhancement Programme as the provider of specific support to individual countries in developing and reforming their professional military education institutions. DEEP Programme is truly able to develop capacity, tighten cooperative and lead towards the standardisation and interoperability. By enhancing democratic institutions, it makes an important contribution to NATO's efforts to project stability in the Euro-Atlantic area and beyond. DEEP numbers, regarding last five years, are impressive, leading to key conclusions on the growing importance of the joint efforts. In 2013: 85 events were involved, 162 Allied experts travelled, 245 partner country instructors participate, in 2014 (respectively): 165 events, 309 Allied experts, 352 partner country instructors, in 2015 (respectively: 186 events, 324 Allied experts, 566 partner country instructors, in 2016 (respectively): 211 undertakings 390 Allied experts, 355 partner country instructors, in 2017 (respectively): 198 events, 426 Allied experts, 331 partner country instructors, in 2018 (respectively): 250 undertakings, 491 Allied experts, 431 partner country instructors. With the support of the experts from more than 70 defence education institutions in NATO member and partner countries, DEEP provides host countries with the assistance needed to respond to the most pressing requirements for modernisation and reform. ADL is becoming an essential part of professional military education and is also one of the fastest growing areas of NATO's technological education and training capabilities, and a tool the DEEP uses to provide support to partner countries. It is of importance to stress that the rapid and unrelenting pace of changes and challenges in cybersecurity and NATO's increased emphasis on improving cybersecurity awareness, preparedness and resilience are the driving forces to develop new courses on cybersecurity. The "Cybersecurity Awareness Micro Course - 10 Principles of Cybersecurity", currently available in Ukrainian, is the good example to follow as far as other NATO DEEP programs are concerned.

\section{References}

1. Defence Education Enhancement Programme (DEEP) https://www.nato.int/cps/en/ natohq/topics_139182.htm (access 14.05.2019)

2. Sanders W. L, Wright S. P., Horn S. P. (1997). Teacher and classroom context effects on student achievement, "Journal of personnel education in education" (Vol. I). pp. 57-77.

3. Gawliczek P. Cyfrowi imigranci i tubylcy. Jak pokonać e-wykluczenie i radzić sobie we zmianami w cyfrowym świecie? "Zeszyty Naukowe KSW", Vol. XLIV, Włocławek 2017, pp. 25-38. 
4. Gawliczek P. Jak wykorzystać nowoczesne media w rodzinie, szkole i na uczelni? Rekomendacje i doświadczenia Kujawskiej Szkoły Wyższej w e Włoclawku z użytkowania platformy e-learningowej LMS ILIAS, Rodzina wobec globalnej zmiany cywilizacyjno-medialnej (ed. R. Brzezińska), Włocławek 2017, pp. 7788.

5. Guzewicz W. Information and communication technologies in the security environment - useful tools or necessary evil? Conclusions from the educational practice at Elk Campus Branch of the University of Warmia and Mazury in Olsztyn, Proceedings of the scientific conference "Security and Russian Threats", Jan Kochanowski University Kielce, 2019, pp. 134-145.

6. Gawliczek P. Militarne i niemilitarne działania hybrydowe. Aspekt edukacyjny, Bezpieczeństwo człowieka a wychowanie, Tom II, Aspekty poznawcze i edukacyjne, Siedlce-Drohiczyn 2016, pp. 201-210.

7. PAP-DIP Reference Curriculum http://www.nato.int/nato_static_fl2014/ assets/pdf/pdf_2009_09/20090908_PAB-DIB_en.pdf_(access 19.05.2019)

8. Generic Officer Professional Military Education Reference Curriculum. http://www.nato.int/

nato_static_fl2014/assets/pdf/pdf_topics/20111202_Generic-Officer-PME-

RC.pdf (access 19.05.2019)

9. Non-Commissioned Officer (NCO) Professional Military Education Reference Curriculum.

http://www.nato.int/nato_static_fl2014/assets/pdf/pdf_2015_10/20151013_1510 13-non-comm-officer-eng.pdf_(access 19.05.2019)

10. Cyber Security: A Generic Reference Curriculum. http://www.nato.int/nato_static_ fl2014 /assets/pdf/pdf_2016_10/1610-cybersecurity-curriculum.pdf__access 19.05.2019)

11. Counterinsurgency

Reference

Curriculum. http://www.nato.int/nato_static_fl2014/assets/pdf/pdf_2017_09/20170904_1709 -counterinsurgency-rc.pdf (access 19.05.2019)

12. Building Integrity (BI) Reference Curriculum. https://www.nato.int/nato_static_fl2014/

assets/pdf/pdf_2017_10/20171129_171031-bi-ref-cur17.pdf (access 19.05.2019)

13. Gawliczek P., Rola komunikacji strategicznej w kreowaniu wizerunku NATO. Refleksje po szczycie w Warszawie. Wykład inauguracyjny 2016/2017. "Zagadnienia Społeczne" 2016, No 2 (6), Niepaństwowa Wyższa Szkoła Pedagogiczna w Białymstoku, pp. 302-313.

14. NATO partners with Polish university for e-learning. https://www.nato.int/cps/en/natohq/news_ _ 144877.htm?selectedLocale=en (access 19.05.2019)

15. NATO and Polish university enhance Ukraine's defence education through elearning https://www.nato.int/cps/en/natohq/news_147038.htm? selectedLocale= en (access 19.05.2019)

16. Enhancing Cybersecurity in Ukraine. https://www.nato.int/cps/en/natohq/ news_159840.htm? selectedLocale=en_(access 19.05.2019) 
17. Jozwiak M. Integration of MOOC Principles into a Language Course Framework for NATO DEEP. A Case Study, "Civitas et Lex" 2018 Vol. 4, pp. 7-14.

18. NATO enhances defence education in Skopje. https://www.nato.int/cps/en/ natohq/news_150539.htm?selectedLocale=en (access 19.05.2019)

19. DEEP ADL solution. Scope and High-Level Requirements, NATO Unclassified, NATO HQ 2018 [unpublished work]

(C) 2019 by the authors; Social development \& Security, Ukrainian. This is an open access article distributed under the terms and conditions of the Creative Commons Attribution (CCBY) license (http://creativecommons.org/licenses/by/4.0/). 